\title{
Topical composition a new alternative in the treatment of burns
}

\begin{abstract}
Introduction: Burns are the culprits of the most serious and devastating trauma that can happen to a human being. In historical references Edinburgh Cockshott et al, described different ways of treating burn patients. A topical composition is a set of elements to bring them together in an order up a new preparation with healing properties.
\end{abstract}

Objective: To demonstrate the effectiveness of a topical composition as an alternative in the treatment of burns.

Methodology: A descriptive study included 28 patients with burns Type A, Type AB and Type B (Benaim classification) were treated minor burns, moderate and higher (classification of the American Burn Association (ABA)), body surface area burned (SCQ) was calculated with the Rule 9 in adults and children with Lund Chart -Bowder. Performing mechanical scrubbing (mechanical drive), the SCQ is covered with sterile gauze impregnated with the topical composition, using closed technique, except the face, neck, genital area and/or anus.

Results: The population consisted of 28 patients with burns Type A, AB and B, average age 23. 3 years, $57 \%$ were males. The most common etiologic agent hot liquids. In burns Type A, SCQ 1 at 9\% tissue regeneration was achieved at an average of 13.1 days in the Type AB with SCQ of 4.5 at $18 \%$ in an average of 22.5 and the Type B with SCQ 1 Al 11\% for an average of 50.7 days. Of which $37 \%$ were minor burns, $24 \%$ moderate and $39 \%$ higher.

Conclusion: With the use of the topical composition, we obtain the benefits of healing in a moist environment, with less frequent and painful cures. Obtaining a functional and anatomical healing in possible aesthetics.

Keywords: topical composition burns, healing, effectiveness, treatment
Volume 5 Issue I - 2018

\author{
Gamboa Guillermo RF,' González \\ Hernández J, ${ }^{2}$ Pat Pech $\mathrm{ME}^{3}$ \\ 'Médico Cirujano, Investigador Independiente \\ ${ }^{2}$ Cirujano General, Hospital Alta Especialidad de la Península de \\ Yucatán, Mexico \\ ${ }^{3}$ Licenciatura en Enfermería y Obstetricia, Hospital General \\ Regional, Mexico
}

Correspondence: Gamboa Guillermo RF, Licenciatura en Enfermería y Obstetricia, Hospital General Regional,Yucatán, México,Tel 9993।62675, Email ricardogamboa8@hotmail.com

Received: August 23, 2017 | Published: January 30, 2018

\section{Introduction}

Burns are the culprits of the most serious and devastating trauma that can happen to a human being. " "The burn is a trauma caused by external physical agents that can be thermal, chemical, electrical or radioactive, that destroy the skin and underlying tissues depending on the depth they reach. ${ }^{2}$ They are an important cause of global morbidity and mortality. ${ }^{3}$ In most of the developed countries they are a source important accidental death, only overcome by car accidents. ${ }^{4}$ The Secretary of Health of Mexico in 2009 reported an increase in the incidence of burns from 109,479 burns recorded in 2007 to 114,385 in 2008. Statistics showed that $5 \%$ of reported burns are severe and $52 \%$ occur in children under 5015 years. ${ }^{5}$ Due to the severity of the trauma, burned patients require special handling, fast and timely from the moment the trauma occurs. ${ }^{6}$ The skin is the protective barrier against the environment. The loss of your integrity as a result of an injury or illness can lead to a serious disability or even the death according to its extension or added complications not controlled. ${ }^{7} \mathrm{~A}$ burn disturbs the normal functions of the skin, being enough that the stratum corneum is altered, so that it loses its barrier capacity. The persistence of an unhealed wound determines the final evolution of the patient. In effect, it is the open wound that perpetuates metabolic alterations, compromises the immune mechanisms, induces protein depletion and malnutrition and opens the doors for sepsis that leads to multiple organ failure, the common denominator of deaths in patients with severe burns. Therefore, the treatment of any burn has the final objective of achieving the closure of the injuries as quickly as possible. This is achieved through a series of general measures and a specific topical treatment of the wound that is established after the general measures. ${ }^{8}$ In historical references to the healing of burns, Cockshott of Edinburgh and Cols, described different ways of treating burn patients. The search for substances to place on wounds, went through an empirical process of test-response, until they were commonly used goat's milk, human breast milk, honey, papyrus dressings, rubber and animal fats. The treatment of that then consisted in the application of the mentioned elements for protection of the wound and the conservation of it in an aseptic state. The management of the burn in the early $20^{\text {th }}$ century involved the use of bandages soaked in sodium bicarbonate, normal saline or zinc oxide. ${ }^{9}$ Among the pharmaceutical formulas is the Lassar paste, which is a preparation frequently used as antiseptic and cutaneous astringent, is composed of oxide or zinc, petrolatum, lanolin and starch in equal parts, and its use in bloody areas is widely diffused..$^{10} \mathrm{~A}$ topical composition is a set of elements that put together in an order they integrate a new preparation with healing properties: this new formula is composed of zinc oxide, mineral oil, petrolatum, beeswax, lanolin, ceresin and starch, substances that have been used together or separately throughout history. Petrolatum and mineral oil have lubricating/moisturizing and emollient properties, creating a barrier on the skin, honey beeswax derived from astringent, antioxidant, healing, anti-inflammatory properties and nutritious, 
rich in vitamin A, lanolin is a natural emollient wax, a mixture of cholesterol and fatty acids, easily absorbed, maintains hydration, zinc oxide has anti-inflammatory, anti-exudative, antiseptic, astringent, decongestant, sedative itching and burning. The topical composition recreates the humid environment, achieving a faster recovery, with less frequent and painful cures that allows improving the conditions for a optimal healing, compared to the traditional healing system. ${ }^{11}$ Today, medicine has a variety of healing techniques, some of which are aggressive and others inaccessible to the common denominator of the population.

\section{Material and methods}

Descriptive, retrospective, longitudinal study, a non-probabilistic sampling was carried out for convenience. We included 28 patients with Type A superficial burns 2, Type AB 2 deep and Type B 3 total thickness (Benaim classification), which were mild, moderate and severe following the classification of the American Burn Association (ABA), Burned body surface (SCQ) was evaluated with the Rule of 9 in adults and children with the Lund - Bowder Chart. Mechanical washing was performed under sedation for patients with SCQ greater than $10 \%$ on the day of admission, the rest of the patient's only mechanical lavage with administration of intravenous analgesic. The mechanical washing was performed with the minimum force (mechanical drag) that allowed to eliminate the remains, both organic and inorganic present in the burns with abundant surgical soap, saline and microdacyn, break and remove the flictenas, cover the burned surfaces with sterile gauzes impregnated with the topical composition, on top of the first layer of gauze was placed a second layer, dressings for greater protection and absorption of the exudates using closed technique, except in face, neck, genital region and/or perianal. Subsequently every 24 hours (the first 7 days, SCQ greater than $10 \%$ ) or 48 to 72 hours according to criteria, the impregnated gauzes were removed with the topical composition, applying microdacyn spray and again covered using the same procedure mentioned above until achieving a tissue regeneration in $95 \%$ or complete. A weekly photographic record was kept, and the following data were also recorded: age, gender, anatomical location, etiological agent, and days of cure. The data was analyzed with the statistical program SPSS for Windows version 21 in Spanish.

\section{Results}

The study population consisted of 28 patients with type A, AB and B burns, of which 3 patients presented type A, AB, B, 38 were treated in total with age range from 2 to 59 years with average age 233 years, of which 5 were under 5 years, the largest age group was 20 to 45 years, $57 \%$ corresponded to the male gender and $48 \%$ to the female Figure 1.

As can be seen in Table 1, in Type A burns with SCQ from 1 to $9 \%$ a tissue regeneration was achieved in an average of 13.1 days, in Type AB with SCQ of 4.5 to $18 \%$ a regeneration was achieved Tissue in an average of 22.5 days and in Type B with SCQ from 1 to $11 \%$ a tissue regeneration was achieved in an average of 50.7 days of these injuries, a patient was of high voltage electricity etiology identifying the entrance site palm and the exit site the plant, achieving complete tissue regeneration in 94 days. 37\% were minor burns, $24 \%$ moderate burns and 39\% were major burns.

It was observed that during cures, the gauze impregnated with the topical composition (closed technique) or the direct application of the topical composition (open technique) interacted with the wounds as an ideal dressing, maintaining a humid physiological environment, favoring autochthonous debridement. Consequently decreasing the frequency of mechanical washes in each cure, there was no report of gauze adhered to the wounds, allowing changes with little or no pain (Figure 1) (Figure 2).

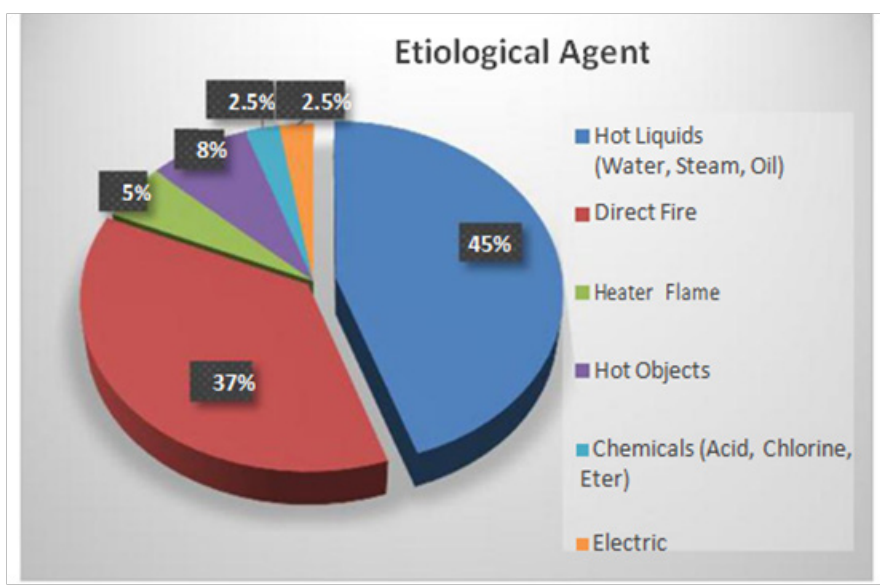

Figure I Data collection instrument.
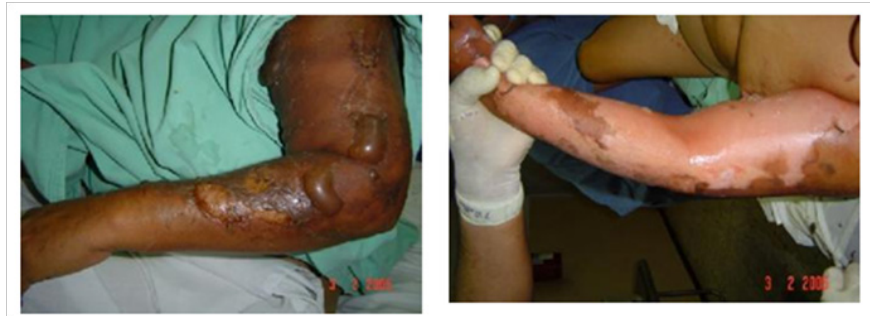

(a)

Female of 35 years of age presents burn ( $6 \% \mathrm{SCQ}$ ) of 2 type A, caused by boiling liquid

(a) Day of admission, after mechanical washing.
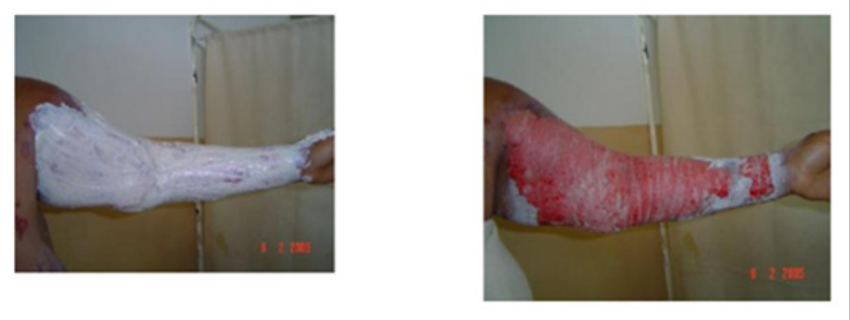

Application of Topical Composition

Day 3

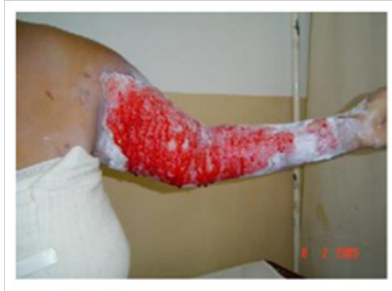

Day 5

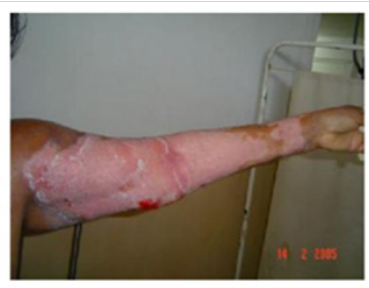

Day 11 of treatment
Figure 2 Closed technique, outpatient management. 


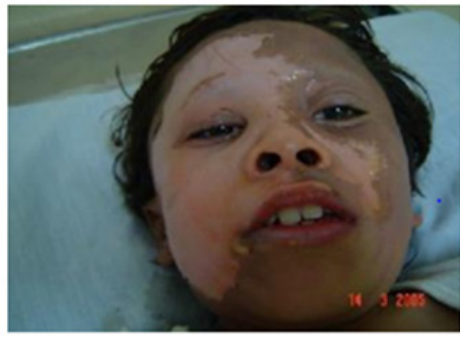

Male of 10 years of age presents facial burn ( $6 \% \mathrm{SCQ})$ of $2^{\circ}$ type A, caused by flame of a heater.

(a) Day of admission, after mechanical washing, the topical composition is applied.

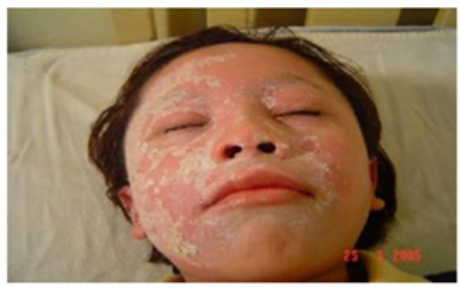

Day 15, front view

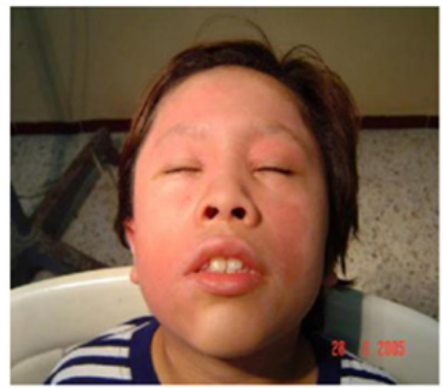

Achieving tissue regeneration after 15 days of treatment, obtaining functional and aesthetic anatomical healing

Figure 3 Open technique, ambulatory management.

Table I

\begin{tabular}{|c|c|c|c|c|c|c|}
\hline \multirow{2}{*}{$\begin{array}{l}\text { Classification } \\
\text { depth } \\
\text { (benaim) }\end{array}$} & \multirow{2}{*}{ SCQ\% } & \multirow{2}{*}{ Anatomical location } & \multirow{2}{*}{ Healing days } & \multicolumn{3}{|c|}{$\begin{array}{l}\text { Severity } \\
\text { American burn association (ABA) }\end{array}$} \\
\hline & & & & Burn less & $\begin{array}{l}\text { Burn } \\
\text { moderate }\end{array}$ & Burn serious \\
\hline \multirow{18}{*}{ TYPEA } & $2 \%$ & Thigh-Leg & 10 & $x$ & & \\
\hline & $4 \%$ & Arm - Antebrazo & 8 & $x$ & & \\
\hline & $4 \%$ & Abdomen & 8 & $x$ & & \\
\hline & $4 \%$ & Shoulder-Antebrazo & 7 & $x$ & & \\
\hline & $4.5 \%$ & Torax - Abdomen & 10 & $x$ & & \\
\hline & $6 \%$ & Arm & 11 & $x$ & & \\
\hline & $8 \%$ & Shoulder & 21 & $x$ & & \\
\hline & $9 \%$ & Arm & 20 & $x$ & & \\
\hline & $9 \%$ & Abdomen & 60 & $x$ & & \\
\hline & $1 \%$ & Perine & 8 & & & $x$ \\
\hline & $2 \%$ & Facial & 6 & & & $x$ \\
\hline & $2 \%$ & Foot & 6 & & & $x$ \\
\hline & $2.5 \%$ & Hand -Palm & 10 & & & $x$ \\
\hline & $3 \%$ & Foot & 12 & & & $x$ \\
\hline & $4 \%$ & Facial & 8 & & & $x$ \\
\hline & $4.5 \%$ & Facial & 8 & & & $x$ \\
\hline & $4.5 \%$ & Facial & 8 & & & $x$ \\
\hline & $6 \%$ & Facial & 15 & & & $x$ \\
\hline
\end{tabular}

Citation: Guillermo GRF, Hernández GJ, Pech PM. Topical composition a new alternative in the treatment of burns. Nurse Care Open Acces J. 20I8;5(I):29-32. DOI: I0.I5406/ncoaj.20I8.05.00II4

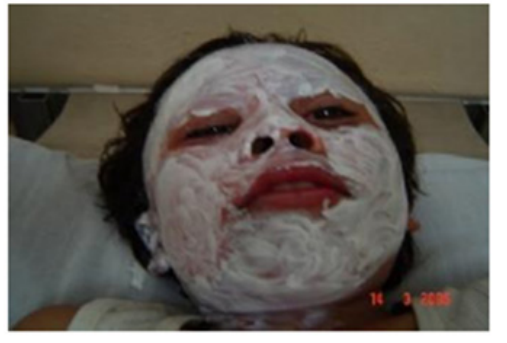

(a)

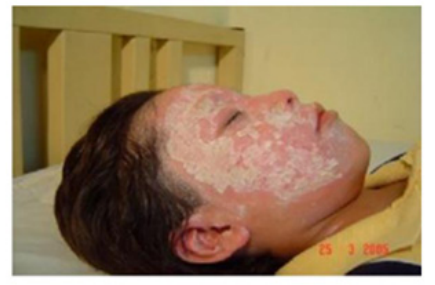

Day 15 , side view

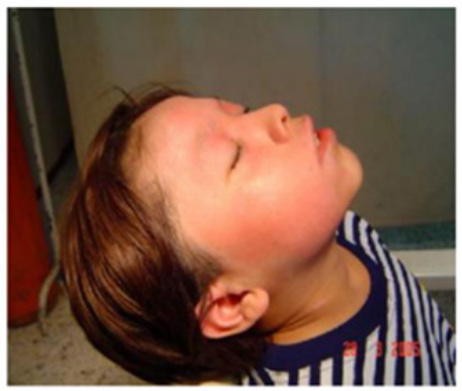

ng 
Table Continued....

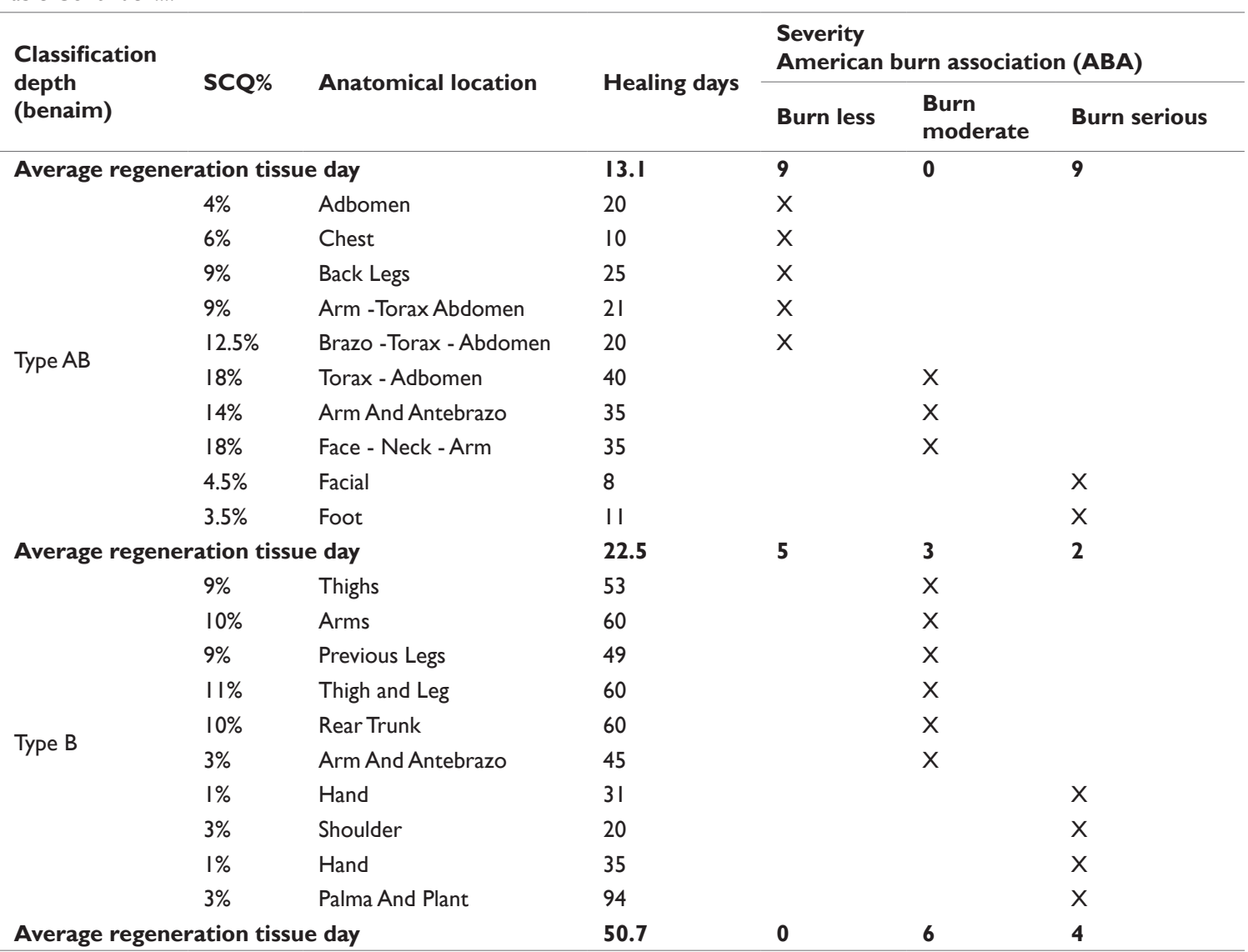

\section{Discussion}

3. Lagos C, Contreras J, González P. Comparación de 2 técnicas de curación en pacientes quemados pediátricos. Rev Ped Elec. 2009;6(3).

Since 1934 the silver nitrate solution became the drug of choice for the care of burns and has continued as a therapeutic agent at present. Its use is not recommended in facial burns, its removal is painful for the patient. With the introduction of the use of the topical composition, the benefits of healing in a moist environment are obtained, relieves pain, favors tissue regeneration, accelerates healing, prevents secondary deepening conditioned by drying, prevents scab formation, and the change and removal of gauze is very well tolerated even in patients under age. Obtaining a functional anatomical healing and as far as possible aesthetic.

\section{Acknowledgments}

None.

\section{Conflict of interest}

The author declares no conflict of interest.

\section{References}

1. Alfaro Dávila M. Quemaduras. Hospital San Juan de Dios, Costa Rica; 2013.

2. Sánchez Medina MT, Santana Molina N, Navarro García R. Manejo de las Quemaduras. En Libro de Ponencias: XXIV Jornadas de Traumatología y Cirugía Ortopédica. Islas Canarias. Biblioteca Universitaria, Mexico: Springer; 2011. p. 35-38.

4. Viñas Díaz JA, Rodríguez JJ, González Rodríguez M. Epidemiología de las lesiones por quemaduras. Rev Ciencias Médicas. 2009;13(4).

5. Orozco Valerio M, Miranda Altamirano R, Méndez Magaña A, et al. T endencia de mortalidad por quemaduras en México, 1979 -2009. Gaceta Medica de México. 2012;(148):349-357.

6. Ramírez Rivero C, Ramírez Rivero M, Ramírez RiveroN. Manejo del Paciente Quemado. Revista de la Facultad de Salud, Colombia: Springer; 2007.

7. Ramírez Hernández GA. Fisiología de la cicatrización cutánea. Revista Faulted de Salud, Colombia. 2010;2(2):69-78.

8. Rodríguez Garcell R, Miquet Romero L. Tratamiento local de la quemadura; 2013.

9. De Los Santos González CE. Historia del tratamiento de las quemaduras. En: Guía básica para el tratamiento del paciente quemado. España; 2004.

10. Suárez Colín A, Salgado RM, Apis Hernández AM, et al. Inducción del tejido de granulación por pasta de Lassar vs colágena -polivinilpirrolidona en úlceras por insuficiencia venosa. Rev Latinoam Cir Plast. 2004;14(1):5-13.

11. Ricardo francisco gamboa guillermo. Composición tópica para el tratamiento de lesiones dérmicas. México; 2005. 